\title{
Why MilitARY MATTERS: Re Colonel AIRD; EX PARTE ALPERT AND THE 'SERVICE CONNECTION' TEST VERSUS THE 'SeRvice Status' TEst: COMPETING APPROACHES TO THE TRIGgERING OF THE DEFENCE POWER
}

\author{
SCOTT GUY* AND BARBARA ANN HOCKING**
}

\begin{abstract}
With political changes afoot in both Australia and the United States, it is timely to review military regimes and remind ourselves how greatly they matter. Section 51(vi) of the Constitution authorises the Commonwealth Parliament to legislate with respect to: 'The naval and military defence of the Commonwealth and of the several States and the control of the forces to execute and maintain the laws of the Commonwealth...' One of the concerns in relation to $s$ 51(vi) has been whether this provision supports the establishment of military tribunals and, further, whether these tribunals can be regarded as exercising judicial power of the Commonwealth and thus be regarded as properly constituted courts for the purposes of Ch III of the Australian Constitution. The High Court's 2004 decision in Re Colonel Aird; Ex parte Alpert has established that military tribunals and, more generally, the military discipline system will be regarded as constitutionally valid and a properly constituted court for the purposes of Ch III provided that it is applied to conduct which can be regarded as 'service connected' or invoked for the purposes of enforcing and maintaining discipline among the defence forces. This article examines the decision in Aird's Case and the associated 'service connection' test as a basis for supporting the constitutional validity of the military tribunal system. The concluding
\end{abstract}

\footnotetext{
* BA (Hons), LLB (Hons) Grad Dip Legal Prac, PhD, Lecturer in Law, Griffith University. ** BA, LLM, PhD, Associate Professor in Law, Queensland University of Technology. We would like to thank Kanchana Kariyawasam for her research assistance. We would also like to thank the anonymous referee and the editors of the Deakin Law Review for their valuable feedback on earlier versions of this article.
} 
178 DEAKIN LAW REVIEW

VOLUME 13 No 2

section of the article develops some further observations on the newly created Australian Military Court.

\section{INTRODUCTION}

The High Court decision in Re Colonel Aird; Ex parte Alpert ${ }^{1}$ in 2004 indicated that the Court has settled for now on the use of a 'service connection' test as the appropriate test with which to evaluate whether military service tribunals are properly exercising their constitutional jurisdiction in accordance with section 51(vi) of the Australian Constitution ('the Constitution'). Section 51(vi) of the Constitution authorises the Commonwealth Parliament to legislate with respect to: 'The naval and military defence of the Commonwealth and of the several States and the control of the forces to execute and maintain the laws of the Commonwealth...' The issue in relation to section 51(vi) has been whether this provision supports the establishment of military tribunals and, further, whether these tribunals can be regarded as exercising the judicial power of the Commonwealth and thus as properly constituted courts for the purposes of Chapter III of the Constitution. The High Court's decision in Re Colonel Aird; Ex parte Alpert has established that military tribunals are constitutionally established provided that they deal with conduct which can be regarded as 'service connected' or are invoked for the purposes of enforcing and maintaining discipline among the defence forces. What is interesting about this case is that the facts were significantly different from those in related previous cases. Hence, the decision represents the establishment and testing of new boundaries to the law. What is perhaps disappointing is that the view expressed by Deane $J$ in earlier cases failed to provide the separation of powers trump-card despite the passionate dissenting view of Kirby J which finds him, and 'not for the first time' agreeing with that approach to so 'fundamental [a] constitutional question'. The High Court split 4:3 in its decision.

\section{Previous Australian Jurisprudence on the CONSTITUTIONALITY OF MILITARY TRIBUNALS AND COURTS MARTIAL}

The use of courts martial and military tribunals as a mechanism for enforcing discipline and trying offences among the armed forces has had a long history.

1 (2004) 220 CLR 308. 
From the seventeenth century, military discipline in the British armed forces was enforced by military commanders and the more serious offences were dealt with by means of courts martial. ${ }^{2}$ Detailed legislation was enacted in the nineteenth century, providing for disciplinary processes in the army and navy through the Naval Discipline Act 1866 (Imp) and the Army Act 1881 (Imp).

The issue pertaining to the constitutional validity of military tribunals and courts martial and whether they do exercise judicial power was first raised in $R v$ Bevan; Ex parte Elias and Gordon ${ }^{3}-$ a case in which two Australian seamen in World War II were sentenced to death under the Naval Discipline Act, via the instrument of a court martial, for the murder of an Australian naval officer. This issue of whether the court martial process constituted a proper exercise of judicial power under Chapter III of the Constitution was the subject of an appeal and the matter proceeded ultimately to the High Court, where Starke J succinctly outlined the issues and law on the matter:

But do they [courts martial/military tribunals] exercise judicial power of the Commonwealth? If so, the proceedings are unwarranted in point of law. The question depends upon the interpretation of the Constitution and whether such courts stand outside the judicial system established under the Constitution. The Parliament has power, subject to the Constitution, to make laws for the peace, order, and good government of the Commonwealth with respect to the naval and military defence of the Commonwealth and of the several States and the control of the forces to execute laws of the Commonwealth and by sec. 61 of the Constitution the command in chief of the naval and military forces of the Commonwealth is vested in the Governor-General as the King's representative.

Under the Constitution of the United States of America the judicial system of the United States is vested in the Supreme Court and in such inferior courts as Congress may from time to time ordain and establish: Cf. Australian Constitution, sec. 71. And the judges hold office during good behaviour (art. III, sec. 1). Power is conferred upon Congress to provide and maintain a navy and to make rules for the government and regulation of the land and naval forces (art. 1, sec. 8, clauses 13, 14). The President is Commander-in-Chief of the army and navy of the United States (art. II, sec. 2, clause 1). And the Fifth Amendment provides that no person shall be held to answer for capital or other infamous crimes unless on a presentment or indictment of a grand jury except in cases arising in the land or naval forces, whereas the Australian Constitution (sec. 80) provides that the trial on

\footnotetext{
${ }^{2}$ For an historical outline of the use of these procedures see Hembury $v$ Chief of General Staff (1998) 193 CLR 641, 667 (Kirby J).

${ }^{3}$ (1942) 66 CLR 452.
} 
indictment of any offence against any law of the Commonwealth shall be by jury but there is no exception in cases arising in the land or naval forces as in the American Constitution. But the frame of the two Constitutions and their provisions, though not identical, are not unlike. The Supreme Court of the United States has resolved that courts-martial established under the laws of the United States form no part of the judicial system of the United States and their proceedings within the limits of their jurisdiction cannot be controlled or revised by civil courts. Thus, in Dynes v. Hoover, Mr. Justice Wayne, delivering the opinion of the Court, said: - "These provisions show that Congress has the power to provide for the trial and punishment of military and naval offences in the manner then and now practised by civilized nations; and that the power to do so is given without any connection between it and the 3rd article of the Constitution defining the judicial power of the United States; indeed, that the two powers are entirely independent of each other" ...

In my opinion the same construction should be given to the constitutional power contained in sec. 51(vi.) of the Australian Constitution. The scope of the defined power is extensive, as is suggested by the decisions of this Court (Joseph v. Colonial Treasurer (N.S.W.); Farey v. Burnett), and though the power contained in sec. 51(vi.) is subject to the Constitution, still the words "naval and military defence of the Commonwealth and the control of the forces to execute and maintain the laws of the Commonwealth," coupled with sec. 69 and the incidental power (sec. 51(xxxix.)) indicate legislative provisions special and peculiar to those forces in the way of discipline and otherwise, and indeed the Court should incline towards a construction that is necessary, not only from a practical, but also from an administrative point of view. ${ }^{4}$

In that case, McTiernan $\mathrm{J}$ also saw no reason to doubt that the legislation conferring judicial power on courts martial was in accordance with Chapter III of the Constitution.

Similarly, in a subsequent decision in $R v$ Cox; Ex parte Smith ${ }^{5}$ Latham CJ, Dixon and Williams JJ held that courts martial could be empowered to hear and determine charges against former soldiers who had been discharged from the forces on the grounds of misconduct without offending Chapter III of the Australian Constitution.

\footnotetext{
4 (1942) 66 CLR 452, 466-8 (notes omitted).

5 (1945) 71 CLR 1.
} 


\section{The DEFENCE ForCE DISCIPLINE ACT 1982 (СTH)}

The Commonwealth has since enacted the Defence Force Discipline Act 1982 (Cth). This Act seeks to create a framework of military service tribunals to try members of the Australian Defence Force ('ADF') for breaches of the provisions of the Act. ${ }^{6}$ According to Stephen Gageler, this framework of service tribunals is essentially a continuation of historic United Kingdom legislation relating to the discipline of the defence forces. ${ }^{7}$ The Act produces a comprehensive code for the maintenance and the enforcement of discipline throughout the three arms of the Australian Defence Force administered by these so-called 'service tribunals'.

The Defence Force Discipline Act covers generally three types of offence. The first type of offence is essentially 'military' in character and concerns, for example, acts related to insubordinate conduct. The second type of offence is essentially criminal in nature and relates to acts such as assault and the falsification of documents. Finally, the third type of offence is related to civilian criminal offences and concerns, specifically, acts such as serious assault and fraud. The Act also includes detailed procedural provisions in respect of arrest, search and custody and the investigation of service offences, as well as provisions establishing a system of appeal and review of convictions and punishments.

Part III of the Act creates a series of offences, most of which are specifically military in nature. These offences include mutiny, desertion, assault on other officers, negligent performance of duty, malingering, and destruction of service property. Section 61 of the Act further refers to and brings to bear the whole range of criminal offences, such as assault, manslaughter, murder and rape, on acts carried out in the Jervis Bay Territory.

It should be noted here that the Jervis Bay Territory is a Territory of the Commonwealth of Australia. It was bought by the Commonwealth Government in 1915 from the State of New South Wales so that the federal capital at Canberra would have access to the sea. In this respect, it was part of the Australian Capital Territory until 1989 when the Australian Capital Territory achieved self government, after which it became a separate

\footnotetext{
${ }^{6}$ For commentaries on the Defence Force Discipline Act 1955 (Cth) see Hyder Gulam 'An Update on Military Discipline - the $20^{\text {th }}$ Anniversary of the Defence Force Discipline Act', (2004) 9 Deakin Law Review 227; Richard Tracey 'The Constitution and Military Justice' (2005) 28 University of New South Wales Law Journal 426.

${ }^{7}$ Stephen Gageler 'Gnawing at File: An Analysis of Re Tracey; Ex parte Ryan' (1990) 20 University of Western Australian Law Review 47, 48.
} 
Territory administered by the Minister for Territories. However, despite this, it should be noted that it is still counted as part of the Australian Capital Territory for the purpose of the ACT's representation in the Senate. In effect, for most purposes, the Jervis Bay Territory is governed under the laws of the Australian Capital Territory, by the so-called 'Jervis Bay Administration' which handles matters normally concerned with local or state government, and which provides primary school teachers and Australian Federal Police staffing. Residents of Jervis Bay have access to the courts of the Australian Capital Territory, but are not separately represented in the Australian Capital Territory Legislative Assembly. As noted, section 62 of the Defence Force Discipline Act makes all Australian Defence Force members, as well as civilian employees, subject to the criminal laws of the Jervis Bay Territory regardless of where the offence occurred. This is thus a legal device which makes Defence personnel subject to the Crimes Act 1914 (Cth), the Criminal Code Act 1995 (Cth) and the criminal law of the Australian Capital Territory - as military law - even if the offence is committed outside Australia.

In this respect, then, a member of the defence force or a civilian employee situated in the Jervis Bay Territory, who acts or omits to act in a way which would constitute a criminal offence in the Jervis Bay Territory, is guilty of a serious offence for the purposes of the Defence Force Discipline Act 1982 (Cth). If the act was committed on a ship that was in waters immediately adjacent to the Jervis Bay Territory then the act will have been committed in the Territory and section 62 will pick up and apply all of the ACT laws that are applicable to that act. In short then, a wide range of offences has been created under section 62 of the Defence Force Discipline Act and this has raised the possibility of a serving member not only being subject to prosecution under this legislation via a military tribunal but also being prosecuted under the criminal jurisdiction of the non-military court system. The assault on a superior officer, an offence under section 25 of the Act, is one example of a situation where a member of the armed forces may be subject to both a court martial and a criminal proceeding in a non-military court. (To some extent, section 190(5) deals with this situation by providing that an officer who has been convicted or acquitted of an offence under the Act through the process of a court martial cannot subsequently be prosecuted for a substantially similar offence in a criminal (non-military) court proceeding.)

The purpose of the Defence Force Discipline Act is to apply the disciplinary provisions contained in the Act to Australian soldiers serving outside of Australia. The provisions of the Act can also be activated in Australia during peacetime where their operation could reasonably be regarded or understood 
as substantially serving the purpose of maintaining, as well as enforcing, service discipline. ${ }^{8}$ The Act also applies in relation to activities that might constitute war crimes. ${ }^{9}$ Under the operation of the Defence Force Discipline Act, section 3A of the Criminal Code Act 1995 (Cth), and the Crimes (Overseas) Act 1964 (Cth), the criminal law jurisdiction of Jervis Bay is extended to certain categories of persons whilst they are in foreign countries and this applies, in particular, to war crimes. In this way Australian jurisdiction is extended to extraterritorial acts that may potentially constitute war crimes (such as acts in relation to prisoners of war) and which would fall under international conventions.

The jurisprudence on the Defence Force Discipline Act indicates two conflicting or competing approaches to its operation. ${ }^{10}$ These can be briefly summarised as, firstly, a 'service status' approach. Under this approach a precondition to the exercise of the defence power and the provisions of the Defence Force Discipline Act is the requirement that the person charged simply be a member of the Australian Defence Force. ${ }^{11}$ The fact that the person is a member of the ADF is a sufficient basis for triggering the operation of the Act and automatically makes the accused liable to punishment under the Commonwealth Criminal Code 1995 (Cth). ${ }^{12}$ As John Devereux argues, this approach 'posits that membership simpliciter of an arm of the ADF makes one liable to punishment under a military code'. ${ }^{13}$ Such an approach is one particularly favoured in the United States and is evident in such Supreme Court decisions as that of Re Solario v United States. ${ }^{14}$

Under the second, competing 'service connection' approach, the degree or extent of connection and association between the offence and the functioning of the military or defence force is considered. For example, the approach takes into account such factors as whether the crime was committed away from the military base; whether its commission took place at a location that was not under military control; whether there was any connection between the defendant's military duties and the particular commission of the criminal act; whether the particular act involved any flouting of military authority;

\footnotetext{
${ }^{8}$ Gulam, above n 6, 228.

${ }^{9}$ Gillian Triggs 'Implementation of the Rome Statute for the International Criminal Court: A Quiet Revolution in Australian Law' (2003) 25 Sydney Law Review 507.

${ }^{10}$ In this particular respect, see John Devereux 'Discipline Abroad: Re Colonel Aird; Ex parte Alpert' (2004) 23 University of Queensland Law Journal 485.

${ }^{11}$ In an American context, see Re Solario v United States 483 US 435 (1987).

${ }^{12}$ See R A Brown 'Military Justice in Australia: W(h)ither Away? The Effects of Re Tracey;

Ex parte Ryan' (1989) 13 Criminal Law Journal 263, 276.

${ }^{13}$ Devereux, above n 10, 487.

${ }^{14} 483$ US 435 (1987).
} 
whether the offence was one, in particular, that should have been prosecuted in a civilian court; and whether a civilian court was present and available, in which the case could alternatively have been prosecuted. ${ }^{15}$

\section{JURISPRUDENCE ON THE DEFENCE FORCE DISCIPLINE ACT 1982 (СTH)}

The former 'service status' approach was particularly reflected in the judgment of Mason CJ, Wilson and Dawson JJ in Re Tracey; Ex parte Ryan ${ }^{16}$ where their Honours declared that:

It is open to Parliament to provide that any conduct which constitutes a civil offence shall constitute a service offence, if committed by a defence member...The proscription of that conduct is relevant to the maintenance of good order and discipline in the defence forces. The power to proscribe such conduct on the part of the defence members is but an instance of Parliament's power to regulate the defence forces and the conduct of the members of those forces. In exercising that power it is for Parliament to decide what it considers necessary and appropriate for the maintenance of good order and discipline in those forces. And Parliament's decision will prevail so long at any rate as the rule which it prescribes is sufficiently connected with the regulation of the forces and the good order and discipline of defence members. ${ }^{17}$

In that case, Sergeant Ryan was charged with being absent without leave, contrary to section 24 of the Defence Force Discipline Act, as well as of falsifying a service document, contrary to section 55 of the Act. The charges were referred to the Defence Force Magistrate and it was argued on Sergeant Ryan's behalf that the Magistrate lacked jurisdiction to hear the matter on the basis that he was not appointed in accordance with the requirement of Chapter III of the Australian Constitution. Relying on both Bevan ${ }^{18}$ and Cox ${ }^{19}$ however, the High Court accepted that a service tribunal, when trying offences under Part III of the Defence Force Discipline Act, had many of the characteristics of a court exercising judicial power in accordance with

\footnotetext{
${ }^{15}$ All of these factors or characteristics were outlined in the United States decision Relford $v$. United States Disciplinary 401 US 355 (1971) where the application of the 'service connection' test reached its most influential level. These factors were also considered in O'Callahan v. Parker 395 US 258 (1969).

${ }^{16}$ (1989) 166 CLR 518.

${ }^{17}$ (1989) 166 CLR 518, 545.

${ }^{18} R$ v Bevan; Ex parte Elias and Gordon, (1942) 66 CLR 452.

${ }^{19} R v$ Cox; Ex parte Smith, (1945) 71 CLR 1.
} 
Chapter III of the Commonwealth Constitution. Specifically, the Court referred to the fact that the accused, Sergeant Ryan, was entitled to legal representation; that he had given evidence under oath; and that the hearing was undertaken in the presence of the accused. All of these factors, according to the High Court, were indicia of a properly constituted court exercising judicial power. According to Mason, Wilson and Dawson JJ:

If offences against military law can extend no further than is thought necessary for the regularity and discipline of the defence forces...this limitation would not preclude Parliament from making it an offence against military law for a defence member to engage in conduct which amounts to a civil offence. $^{20}$

Their Honours were also mindful of the difficulties that were experienced in the United States following the handing down of the decision in O'Callahan $v$ Parker. ${ }^{21}$ In that case it was held that the jurisdiction of a court martial to try a member of the armed forces depended upon the offence charged having a 'service connection'. In seeking to apply this test, the United States jurisprudence has concerned conflicting decisions that have turned on subtle distinctions. For example, a military tribunal might have jurisdiction if the offence was committed on the military base but not if it was committed a few metres outside the perimeter. ${ }^{22}$ Similarly, drugs taken off the base in off-duty hours might affect the later performance of military duties but service tribunals in the United States have been divided on whether or not they had jurisdiction to deal with the charges of illicit drug use. ${ }^{23}$ The uncertainty which had developed up to 1987 led the United States Supreme Court in Solorio $v$ United States ${ }^{24}$ to hold that military courts would have the requisite jurisdiction if the accused was a member of the armed forces at the time of the commission of the offence - in other words the Court adopted the 'service status' test as outlined above. Accordingly, mindful of these concerns, Brennan and Toohey JJ sought to reconcile our own constitutional objectives and declared in Re Tracey that:

There are two sets of constitutional objectives to be reconciled. The first set of objectives, detailed by s 51(vi), consists of the defence of the Commonwealth and the several States and the control of the armed forces. To achieve these objectives, it is appropriate to repose in service authorities

\footnotetext{
${ }^{20}$ Re Tracey; Ex parte Ryan (1989) 166 CLR 518, 545.

${ }^{21} 395$ US 258 (1969).

${ }^{22}$ Re Solorio v United States 483 US 435 (1987).

${ }^{23}$ See Richard Tracey 'The Constitution and Military Justice' (2005) 28 University of New South Wales Law Journal 426, 431; O'Callahan v. Parker 395 US 258 (1969).

${ }^{24} 483$ US 435 (1987).
} 
a broad authority, to be exercised according to the exigencies of the time, place and circumstances, to impose discipline on defence members and defend civilians. The second set of objectives, dictated both by Ch. III and s 108 of the Constitution and by the constitutional history we have traced, consist [sic] of the recognition of pre-ordinate jurisdiction of the civil rights and protection of the civil rights which those courts assure alike to civilians and defence civilians who are charged with criminal offences. To achieve these objectives civil jurisdiction should be exercised when it can conveniently and appropriately be invoked and the jurisdiction of service tribunals should not be invoked, except for the purpose of maintaining and enforcing service discipline. These two sets of constitutional imperatives point to the limits of the valid operation of the Discipline Act. It may not impair civil jurisdiction but it may empower service tribunals to maintain or enforce discipline. Therefore, proceedings may be brought against a defence member or a defence civilian for a service offence if, but only if, those proceedings can reasonably be regarded as substantially serving the purpose of maintaining or enforcing service discipline. ${ }^{25}$

These dicta of the judges provide the outlines of a competing test that has been used to trigger the operation of the defence power, as well as providing a constitutional basis for the exercise of judicial jurisdiction on the part of courts martial and military tribunals when enforcing the provisions of the Defence Force Discipline Act. This has been termed a 'service connection' approach. As part of this approach, it has to be shown that the charging of the person contributes to, or promotes, military discipline and the effective regulation and functioning of the armed forces. ${ }^{26}$ It was this approach which was adopted by Deane $\mathrm{J}$ in Re Tracey in holding that the jurisdiction of service tribunals would only be constitutionally triggered where they dealt with 'exclusively disciplinary offences'. ${ }^{27}$ Similarly, Gaudron J held that courts martial would not have jurisdiction where the matter could be properly dealt with a civil law court. ${ }^{28}$ In consequence, Sergeant Ryan was convicted of the charge of being absent without leave, but was acquitted of the charge relating to the falsification of service documents.

In a six to one majority the High Court found that the Defence Force Magistrate had the power and the jurisdiction to hear the charges which were levelled against Sergeant Ryan. In reaching this conclusion, the High Court

\footnotetext{
${ }^{25}$ Re Tracey; Ex parte Ryan (1989) 166 CLR 518, 569-70 (emphasis added).

${ }^{26}$ Devereux, above n 10, 487. As Devereux argues: ‘...in order for the Act's jurisdiction to arise in respect of an individual service member, the nature of the transgression with which the service member was charged must be such that prosecution and conviction would ensure enforcement or maintenance of military discipline.'

${ }^{27}$ (1989) 166 CLR 518, 591.

${ }^{28}$ Ibid 599.
} 
submitted that it was sufficient, to attract the operation of the provisions of the Defence Force Discipline Act, that Sergeant Ryan was a member of the ADF. Mason CJ, together with Wilson and Dawson JJ, adopted a particularly wide approach in this respect. They declared that:

it is not possible to draw a clear and satisfactory line between offences committed by defence force members which are of a military character and those which are not. ${ }^{29}$

Their Honours were of the opinion that it was open to Parliament to provide that any conduct which constituted a civil offence could also be regarded as a service offence if it was committed by a defence member. This was because - according to their Honours - the commission of civil offences was, in fact, sufficiently connected with the regulation of the forces and the good organisation and discipline of defence members. ${ }^{30}$ The High Court justices here would seem to have repudiated the notion of the 'service connection' test and the requirement for a connection or association between the charging of the member of the ADF and the effective regulation and functioning of the military. As Devereux argues, according to this approach 'membership simpliciter of an arm of the ADF makes one liable to punishment under a Military Code'. ${ }^{31}$

In an associated context, their Honours also upheld the validity or constitutionality of the exercise of judicial power by the tribunal on which the Defence Force Magistrate sat - even despite the fact that the service tribunal was not a Chapter III Court for the purposes of section 71 of the Constitution. $^{32}$ Their Honours held that, although a service tribunal does exercise judicial power, it does not exercise the judicial power of the Commonwealth. This was particularly so because the power to make laws with respect to the defence of the Commonwealth under section 51(vi) of the Constitution in fact contained a power to enact a disciplinary code outside of Chapter III and to impose on those administering it a duty to act judicially. ${ }^{33}$ Such an approach to the nature of service tribunals would in one view be

\footnotetext{
${ }^{29}$ Ibid 544.

${ }^{30}$ Ibid 544. See also Re Nolan; Ex parte Young (1991) 172 CLR 460 at 474-5 per Mason CJ and Dawson J.

${ }^{31}$ Devereux, above n 10, 487.

32 (1989) 166 CLR 518, 545.

${ }^{33}$ Cf Re Nolan (1991) 172 CLR 460 where Brennan and Toohey JJ referred to the 'apparent exception' (at 479) but only to later insist that 'there can be no real exception' and to emphasise 'the imperative of Ch. III of the Constitution that jurisdiction to hear and determine charges of officers against a law of the Commonwealth can be vested only in Ch. III courts': (1991) 172 CLR 460, 480.
} 
attractive, since it recognises the distinctive nature of defence forces and the specific, arguably unique, set of policy considerations that need to be engaged with when adjudicating on actions involving members of the forces. There are, however, persuasive reasons for caution in this regard. This exception to the separation of powers doctrine, as applied to military tribunals would therefore seem to be of limited application and operation. As Andrew Mitchell and Tania Voon comment:

for reasons of practicality and national security, an exception to the separation of powers doctrine allows service tribunals to exercise the judicial power of the Commonwealth. However, power extends only to the minimum degree necessary to enforce military discipline, and no further. Thus, in ordinary circumstances service tribunals should only be entitled to hear exclusively disciplinary offences... In circumstances of wartime and service outside Australia, service tribunals should be able to hear offences that are substantially similar or identical to civil offences. ${ }^{34}$

Despite this, Brennan and Toohey JJ adopted a narrower or more limited view of the power or jurisdiction of the Defence Force Magistrate to hear the case of Sergeant Ryan. Their Honours, in particular, were not prepared to go as far as Mason CJ, Wilson and Dawson JJ with regard to the ambit or operation of section 51(vi), essentially adopting a more 'service' oriented approach. For example, at one point they declared that

proceedings may be brought against defence members or a defence civilian for a service offence if, but only if, those proceedings can reasonably be regarded as substantially serving the purpose of maintaining or enforcing service discipline. ${ }^{35}$

The judgments of the other members of the High Court seemed to be consistent with this approach, emphasising the need for the application of the Act to promote, in general, military or defence force discipline. Deane J, for example, was of the view that jurisdiction could be validly conferred on a service tribunal only to the extent that it related to exclusively disciplinary offences. According to his Honour:

To ignore the significance of the doctrine or to discount the importance of safeguarding the true independence of the judicature on which the doctrine

\footnotetext{
${ }^{34}$ Andrew Mitchell and Tania Voon 'Defence of the Indefensible? Realising the Constitutional Validity of Military Service Tribunals' (1999) 27 Federal Law Review 499, 525; see also Andrew Mitchell and Tania Voon 'Justice at the Sharp End - Improving Australia's Military Justice System' (2005) 28 University of New South Wales Law Journal 396.

${ }^{35}$ (1989) 166 CLR 518, 570.
} 
is predicated is to run the risk of undermining, or even subverting, the Constitution's only general guarantee of due process. ${ }^{36}$

According to Deane J, powers of service tribunals should be limited to the necessity for the maintenance and the enforcement of military discipline and - in those cases relating to offences that were committed in peacetime - 'to dealing with exclusively disciplinary offences' ${ }^{37}$ As Richard Tracey argues, this approach essentially turned on the issue of whether the grant of jurisdiction would substantially serve the purpose of maintaining or enforcing discipline of the defence forces. ${ }^{38}$

A similarly narrow or restrictive approach was advocated by Gaudron $\mathrm{J}$, who submitted that jurisdiction could only be validly conferred on a service tribunal to the extent that it related to charges of service offences that were not substantially the same as civil court offences. By this view, the operation of the defence power and the Defence Force Discipline Act ought to be confined to one that promoted military discipline and, in particular, to the effective regulation of the defence force. According to her Honour:

[laws were] reasonably capable of being viewed as appropriate and adapted to the control of the forces when regard is had to what is necessary from a practical administrative point of view. ${ }^{39}$

The High Court's decision in Re Tracey, therefore, illustrates the competing approaches to the operation of the Defence Force Discipline Act and the triggering of its jurisdiction under the constitutional defence power. It highlights the lack of conceptual clarity in the Court's approach, so far, to the jurisdiction of service tribunals. Of particular note is Deane J's view of the significance of the separation of powers doctrine in the Constitution: which he terms 'the Constitution's only general guarantee of due process', and which prompts Andrew Mitchell and Tania Voon to remark favourably that:

By starting from the position that service tribunals should not be entitled to exercise judicial power, and that departure from this position should be allowed only in exceptional circumstances, this approach gives due weight to the separation of powers doctrine as a safeguard of individual rights. ${ }^{40}$

\footnotetext{
${ }^{36}$ Ibid 580 .

${ }^{37}$ (1989) 166 CLR 518, 591.

${ }^{38}$ Tracey, above n 23, 435.

${ }^{39}$ (1989) 166 CLR 518, 600.

${ }^{40}$ Mitchell and Voon, above n 34, 519.
} 
One important possible explanation for the apparent lack of precision in the High Court's approach to the Act and the defence power over this series of cases, though all upheld the use of the power, could be the changing (defence or military) circumstances and conditions within which the Court operates and the consequent need to retain a degree of flexibility when approaching the issue of defence and the Australian Defence Force. As George Williams argues when examining High Court approaches to the defence power:

The central High Court doctrine concerning the defence power is that the power waxes and wanes. It is a fixed concept with a changing content because its scope depends on Australia's defence needs at any given time... The conditions that determine the scope of the power ... are factual conditions such as ... whether Australia is currently at war or facing a real or perceived threat of invasion... ${ }^{41}$

\section{The 'Service Connection' Test ANd its Associated JURISPRUDENCE}

The latter 'service connection' approach considers the degree or extent of connection and association between the offence and the functioning of the military or defence force. For example, it takes into account such factors as whether the crime was committed away from the military base; whether its commission took place at a location that was not under military control; whether there was any connection between the defendant's military duties and the commission of the criminal act; whether the act involved any flouting of military authority; whether the offence was one that should have been prosecuted in a civilian court; and whether a civilian court was present and available in which the case could have been prosecuted. ${ }^{42}$ Such an approach was well summarised by Toohey and Brennan $\mathrm{JJ}$ in the High Court decision in Re Nolan; Ex parte Young ${ }^{43}$ where their Honours declared that:

Service discipline is not merely punishment for wrongdoing. It embraces the maintenance of standards and morale in the service community of which the offender is a member, the preservation of respect for, and the habit of

\footnotetext{
${ }^{41}$ George Williams 'Defence Power' in Tony Blackshield, Michael Coper and George Williams (eds), The Oxford Companion to the High Court of Australia. South Melbourne: Oxford University Press, 2001, 200-1.

${ }^{42}$ All of these factors or characteristics were outlined in the United States decision Relford $v$ United States Disciplinary Barracks, Ft Leavenworth 401 US 355 (1971) where the application of the 'service connection' test reached its most influential level. These factors were also considered in O'Callahan v Parker 395 US 258 (1969).

${ }^{43}$ (1991) 172 CLR 460.
} 
obedience to, lawful service authority and the enhancing of efficiency in the performance of service functions. Here, the charges are obviously 'service connected' but this is not the ultimate criterion though it is an important element in determining whether proceedings on those charges could reasonably be regarded as serving the purpose of maintaining and enforcing service discipline. ${ }^{44}$

The High Court judges' divergent attitudes to the operation of the defence power and the application of disciplinary proceedings to ADF members were particularly apparent in Re Nolan; Ex parte Young. ${ }^{45}$ In that case, a member of the Australian Defence Force, Sergeant Young, was charged with falsifying a service document in order to receive an amount of pay greater than that to which he was entitled. Young contended that the offences charged were those more connected with general law and that the Defence Force Magistrate did not have the jurisdiction to hear the matter. In determining the operation of the Magistrate's jurisdiction, Mason CJ and Dawson $\mathrm{J}$ indicated that he had wide powers and gave the proceedings under the Defence Force Magistrate a broad operation. Their Honours held that it was open to Parliament to provide that any conduct which constitutes a civil offence could also be understood as a service offence if it was committed by a defence member and could thereby be triable by a service tribunal. ${ }^{46}$ In effect, the fact that the offence applied to a member of the Australian Defence Force was sufficient to bring it within the jurisdiction of the Magistrate. Thus, their Honours found that the Defence Force Magistrate did have jurisdiction to hear the particular charge.

Brennan and Toohey JJ were also in the majority but sought to impose limitations on the jurisdiction of the Magistrate. They declared, in particular, that jurisdiction was only triggered when it could reasonably be said that the maintenance and the enforcement of discipline would be served by charges being heard before a service tribunal constituted by a Defence Force Magistrate. ${ }^{47}$ However in Aird, Kirby, Callinan and Heydon JJ considered that the offence could be tried in Australia, were it triable by a service tribunal. Mitchell and Voon's insight as to this is, however, that 'neither result necessarily follows', for

[t] he interests of military effectiveness and true military justice are best served by conceding that service tribunals may operate outside Chapter III

\footnotetext{
${ }^{44}$ Ibid 489.

${ }^{45}$ Ibid 460 .

${ }^{46}$ Ibid 474-5.

${ }^{47}$ Ibid 489.
} 
only in exceptional circumstances associated with war or combat, or in the absence of a civilian equivalent in Australian law to an offence that is necessary for the enforcement of military discipline. ${ }^{48}$

The approach of Brennan and Toohey JJ would seem closely to approximate the 'service connection' test and would appear, in fact, to coincide with the method adopted (as previously outlined) by both Deane $\mathrm{J}$ and Gaudron $\mathrm{J}$ in the preceding decision in Re Tracey. As Hyder Gulam argues, according to this latter, more limited, approach:

The power conferred by s 51(vi) of the Australian Constitution does not extend to the making of a law to punish defence members and defence civilians for their conduct unless the proceedings taken to punish them can be reasonably regarded as substantially serving the purpose of maintaining or enforcing service discipline. ${ }^{49}$

This 'service connection' approach was further emphasised and extended in the dissenting judgment of Deane $\mathbf{J}$ who held that, so far as offences that were committed in peacetime were concerned, jurisdiction could be validly conferred on a service tribunal only to the extent that it related to what were considered to be exclusively disciplinary offences. ${ }^{50}$ Thus, Deane J sought to distinguish between essentially civil offences and those offences which were distinctly or characteristically related to the operation of the defence forces. According to his Honour:

I have great difficulty with the conclusion of the majority in Re Tracey that, if the provisions of the Act validly confer jurisdiction upon service tribunals to deal comprehensively with the disciplinary and community aspects of at least some service-related offences, the provisions of s 190(3) and (5) are not valid to the extent that they deprive State courts of jurisdiction to deal with substantially the same offence after the service tribunal has exercised that comprehensive jurisdiction. ${ }^{51}$

Similarly, Gaudron J - reflecting her previous views in Re Nolan - held that jurisdiction could be legitimately conferred on a service tribunal only to the extent that it related exclusively to disciplinary offences. Like Deane J, Gaudron $\mathbf{J}$ highlighted the need to draw a distinction between offences that could be enforced or adjudicated on by ordinary Chapter III courts and

\footnotetext{
${ }^{48}$ Mitchell and Voon, above n 34 (2005), 412.

${ }^{49}$ Gulam, above n 6, 233-4.

${ }^{50}$ (1991) 172 CLR 460, 491.

${ }^{51}$ Ibid.
} 
offences relating to military discipline that could be enforced by military tribunals:

In my view, if the power or any part of the power which the Act confers on service tribunals is to be seen as outside Ch. III of the Constitution, it must be by reason of the character of the law in so far as it creates service offences. It cannot be taken outside Ch. III simply because it is a power over persons subject to military discipline. Persons in that situation do not, on that account, become immune from the operation of the general law. Nor are they, on that account, deprived of the protection of the law. Nor can the power of service tribunals to hear and determine service offences be taken outside Ch. III simply by reason of the events of history. Times change. Whatever may have been the situation in earlier times, there is now no insuperable difficulty in bringing members of the armed forces stationed in Australia before the ordinary courts when questions arise as to the consequence, if any, which the general criminal law imposes by reason of their conduct in Australia. ${ }^{52}$

A subsequent decision in which the High Court had cause again to consider the defence power and the nature of the jurisdiction of the defence tribunal was that of Re Tyler; Ex parte Foley ${ }^{53}$ This decision concerned a member of the Australian Defence Force, Wing-commander Foley, who was charged before a general court martial for appropriating the sum of $\$ 24,761.00$ from the Commonwealth. Foley sought to defend himself against the charges on the basis that the charges were similar to those contained in the federal Crimes Act 1914 (Cth) and should therefore have have been adjudicated on by an ordinary court. Furthermore, he argued that because the general court martial was not constituted in accordance with Chapter III of the Constitution, it was one that had no power or jurisdiction to exercise the judicial power of the Commonwealth. Mason CJ and Dawson J held that a general court martial had the necessary jurisdiction to hear a charge against a defence member that he had dishonestly appropriated property of the Commonwealth. ${ }^{54}$ They declared that a law applying to an Australian defence force member would, in itself, be sufficient as a basis on which to found the jurisdiction of the Defence Force Magistrate. Their Honours stated:

Moreover ... we accepted the experience of the United States that it is not possible to draw a clear and satisfactory line between those offences committed by defence members which are of a military character and those which are not. We considered that even if offences against military law can

\footnotetext{
52 (1991) 172 CLR 488, 497. A similar view was also expressed by McHugh J.

${ }^{53}$ (1994) 181 CLR 18.

${ }^{54}$ Ibid 26.
} 
extend no further than is thought necessary for the regularity and discipline of the defence forces, it was within the power of Parliament to provide that any conduct which constitutes a civil offence shall constitute a service offence if committed by a defence member. ${ }^{55}$

Brennan and Toohey JJ reached a similar conclusion regarding the legitimacy of the service tribunal's jurisdiction, but arrived at this finding through more restrictive reasoning than that contained in the judgment of Mason CJ and Dawson J. Their Honours declared that Parliament did, in fact, have the necessary power under section 51(vi) to provide for a trial of offences before a court martial, but that Parliament only had that jurisdiction which has as its aim the overall purpose of maintaining service discipline. As their Honours declared:

The system of discipline required for the proper organization of a defence force may, we said, be administered judicially, not as part of the judicature enacted under Ch. III, but as part of the organization of the force itself. We concluded that the power to make laws with respect to defence contains within it the power to enact a disciplinary code standing outside Ch. III and to impose upon those administering that code the duty to act judicially. It was implicit in the view which we expressed that the trial of service offences might be by way of court martial and not by way of trial by jury since the former is not a trial on indictment and s. 80 of the Constitution has no application. ${ }^{56}$

Moreover, their Honours, in reiterating the view outlined in Re Nolan; Ex parte Young, declared that:

The proscription of that conduct is relevant to the maintenance of good order and discipline in the defence forces; so long as the rule prescribed is sufficiently connected with the regulation of the defence forces and the good order and discipline of members, it will be valid. Indeed, we do not understand how it can be suggested that the prescription of a rule of conduct to be observed by defence members, when that rule of conduct is required to be observed by the general community for the good of society, is not sufficiently connected with the regulation of the defence forces and the good order and discipline of those forces. Plainly Parliament can take the view that what is good for society is good for the regulation of the defence forces and can give effect to that view by creating service offences which are cumulative upon, rather than in substitution for, civil offences. ${ }^{57}$

\footnotetext{
${ }^{55}$ Ibid.

${ }^{56}$ Ibid 25-6.

${ }^{57}$ Ibid 25 citing the majority in Re Nolan; Ex parte Young (1991) 172 CLR 460, 474-5.
} 
They found that the charge of appropriating the sum of Commonwealth money did promote service discipline. Such an understanding again reflected significant aspects of the 'service connection' approach. For example, at one point in the judgment their Honours declared that:

In our view the proceedings in question can reasonably be regarded as substantially serving the purpose of maintaining or enforcing service discipline. The factors leading to that conclusion are as follows. The charge involves a misappropriation of 'service property' as that term is defined in $\mathrm{s}$ 3(1) of the Act. The T.R.A. scheme giving rise to the charge is a scheme administered by the Australian Defence Force for the benefit of defence members. The authority for the T.R.A. scheme is to be found in s 58B of the Defence Act 1903 (Cth) and the elements of the scheme, in the form of INDMAN 0503, constitute a defence instruction (General) which is a 'general order' as defined in s 3(1) of the Act. ${ }^{58}$

Gaudron $\mathrm{J}$ also adopted a similarly restrictive reasoning, holding that jurisdiction could be validly conferred on a service tribunal only where it related to, or involved, the promotion of military discipline. She argued that only where the charge could, in effect, be characterised as a distinctively military offence would the jurisdiction of the service tribunal be triggered. Her Honour stated:

I have considered afresh whether Parliament can validly authorise service tribunals, which plainly are not courts of the kind contemplated by Ch. III of the Constitution, to hear and determine charges under the Act in relation to acts or omissions which, although called 'service offences', are, in essence, the same or substantially the same as criminal offences under the general law. I remain firmly of the view that persons who are subject to military discipline cannot, on that account, be made 'immune from the operation of the general law ... or deprived of [its] protection. In particular, they cannot, on that account, be deprived of the protection which flows from Ch. III of the Constitution. ${ }^{59}$

In some respects, these above cases were relatively simple and straightforward for the High Court since they involved prosecutions of members of the Australian Defence Force who were on duty and who were purporting to act in the exercise of their duties. Under these circumstances, it was relatively easy for the High Court to find that the prosecutions related to promoting military defence and discipline. What is more contentious or controversial, however, is the situation where a service tribunal seeks to

\footnotetext{
${ }^{58}$ Ibid 31 .

${ }^{59}$ Ibid 35.
} 
invoke jurisdiction in cases where charges are laid against ADF members who are on leave or who are acting in a purely private or personal capacity. It was precisely this latter situation which arose for the consideration of the Court in the case of Re Colonial Aird; Ex parte Alpert ${ }^{60}$ which is the subject of significant attention below. The differing fact situation in Aird marks out its significance jurisprudentially, for as John Devereux writes:

All three prior High Court cases focused on prosecutions of members of the ADF, while those members were on duty and were purporting to act in the exercise of their duties. The accused in Aird was in an entirely different situation. He was a member of the ADF on leave, not purporting to act in the exercise of his duties. ${ }^{61}$

\section{RE Colonel Aird; EX PARTE ALPERT}

Aird's case ${ }^{62}$ concerned a soldier, Private Alpert, who was in the regular army in the Australian Defence Forces and who was deployed to the Royal Malaysian Air Force Base at Butterworth in Malaysia. In September 2001 he was granted stand down leave for the last week of September. This leave had to be taken in the peninsula area of Malaysia, Thailand or Singapore unless express prior approval was obtained from the Commanding Officer. Accordingly, Private Alpert elected to take that leave in Phuket in Thailand, but, while the leave restrictions might indicate a level of military control, he entered Thailand on his civilian passport using no form of military identification. There was no Status of Forces Agreement with the Kingdom of Thailand maintaining Australian jurisdiction over visiting Australian service personnel. Therefore by all accounts it was a recreational visit.

It was while Private Alpert was on that recreational leave, during which he paid for himself and did not wear uniform or manifest non-civilian accoutrements, that he allegedly committed the offence. A woman alleged that Private Alpert raped her in the early hours of 29 September 2001 at Patong Beach, Phuket. In November 2001, in a subsequent letter to the Commanding Officer of the $6^{\text {th }}$ Royal Australian Regiment at the unit's headquarters in Brisbane, the young woman then formally alleged that Private Alpert, who was ironically acting as a military prosecutor within the Australian Defence Forces at the time, had raped her, and sought details as to

${ }^{60}$ (2004) 220 CLR 308.

${ }^{61}$ Devereux, above n 10, 490.

${ }^{62}$ (2004) 220 CLR 308. 
the steps that she would need to take to press a charge of rape against Private Alpert.

Private Alpert was charged with contravening section 61 of the Defence Force Discipline Act which was drafted to incorporate into the Act all of the provisions of the Crimes Act 1900 (ACT). Section 54 of the Crimes Act made it an offence for a person to engage in

sexual intercourse with another person without the consent of that other person and [knowing] that that other person does not consent or [being] reckless as to whether that other person consents, to the sexual intercourse

Section 9 of the Defence Force Discipline Act, furthermore, purported to give that Act extra-territorial effect. According to section 9:

The provisions of this Act apply, according to their tenor, both in and outside Australia but do not apply in relation to any person outside Australia unless that person is a defence member or a defence civilian.

Therefore, the offence provisions that were contained in the Crimes Act and, in particular, the offence relating to rape had extra-territorial operation or effect. As Richard Tracey observes:

[Section] 61 of the Act picks up and makes applicable to service personnel the full panoply of the criminal law as it applies in the Jervis Bay Territory. A service member who acts or omits to act such as to commit (anywhere in the world) an offence that which would constitute a criminal offence in the Jervis Bay Territory, is guilty of a service offence for the purposes of the Defence Force Disciplinary Act 1982 (Cth). A very wide range of offences were thus created. There was a significant risk that the same act might render a service member liable to prosecution in both a service tribunal and a civil court for what could be both an offence under the Act and a civilian criminal offence. ${ }^{63}$

Alpert submitted that section 61 of the Defence Force Discipline Act should not apply to him as he was neither in uniform nor was he on duty at the time of the commission of the offence. He argued that ordinary criminal law should be the relevant applicable law and that the service tribunal and Defence Force Magistrate had no jurisdiction to entertain the offence as constituted under the Defence Force Discipline Act.

${ }^{63}$ Tracey, above n 23, 429. 
By a majority of $4: 3$ the High Court found that the service tribunal had the necessary jurisdiction to hear the charge against Alpert in the circumstances of the alleged offence. With this decision, despite the narrow majority, the High Court would seem to have finally settled on a 'service connection' approach to the issue of the jurisdiction of service tribunals. Such an approach found favour with Gleeson CJ and McHugh, Callinan and Heydon JJ. McHugh J, for example, focused on whether the grant of jurisdiction to the magistrate under the Defence Force Discipline Act would serve the purpose of maintaining or enforcing discipline of the defence forces, thereby clearly indicating his support for the 'service connection' test. He was of the view that significant anti-social conduct, such as the commission of rape and sexual assault, 'would have a direct impact on the morale and discipline of the Defence Force' ${ }^{64}$ Specifically, he held that the Defence Force Discipline Act was required to ensure that crimes of violence, such as rape, were not committed within the Australian Defence Force and that discipline was thus an important pre-condition for the effective operation of the force:

It is central to a disciplined force that its members are not persons who engage in uncontrolled violence. And it need hardly be said that other members of the Defence Force will be reluctant to serve with personnel who are guilty rape or sexual assault. This may be out of fear for personal safety or rejection of such conduct or both. ${ }^{65}$

Furthermore, McHugh $\mathrm{J}$ considered that members of the ADF were fundamentally different from private citizens travelling overseas as they would be perceived as representatives of the Australian government and this was identified as an important factor in determining whether a relevant 'service connection' was established. According to McHugh J:

In determining whether the standards of conduct imposed on Defence Force personnel by reference to the legislation of the Australian Capital Territory have the potential to maintain and enhance the discipline of the Defence Force, an important factor is that, when overseas, they are likely to be perceived by the government of the foreign country and members of the local population as representatives of the Australian government. In this respect, they are different from ordinary Australians who visit a foreign country as tourists. It is not to the point that, so far as dress and other matters are concerned, they cannot be distinguished from an ordinary Australian tourist. ${ }^{66}$

\footnotetext{
${ }^{64}$ (2004) 220 CLR 308, 323.

${ }^{65}$ Ibid 323-324.

${ }^{66}$ Ibid 323.
} 
McHugh $\mathrm{J}$ was of the view that there were factors which connected the accused with his Australian Defence Force service. In particular, he had gone to Thailand by virtue of his deployment, he was not a free agent who was permitted to take leave wherever he wished, and he was subject to immediate recall to his duty at any time:

First he was in Malaysia and thereafter Thailand as a result of his deployment by and service with the Australian Defence Force. Indeed, his presence in Thailand resulted from his military service because his recreation leave arose out of his military service and was no doubt designed to ensure that the prosecutor [Private Alpert] would be better able to carry out his military duties. Furthermore, he was not a free agent who could visit any country that he wished. ${ }^{67}$

Accordingly, McHugh J concluded that:

I would have thought that it was beyond argument that ... the defence power extended to making it an offence for a serving member of the armed forces to commit the offence of rape while on leave in a foreign country. ${ }^{68}$

Gleeson CJ and Gummow J agreed with this analysis and with McHugh J's essentially adopting a 'service connection' approach. According to Gleeson $\mathrm{CJ}$, the imposition of Australian laws on members of the Australian Defence Force serving overseas was an entirely legitimate means of promoting the Defence Force's discipline and its effective operation. Gummow J adopted a similar perspective. While not explicitly advocating either a 'service status' or a 'service connection' approach he did cite with approval comments that were expressed by Mason CJ, Wilson and Dawson JJ in Re Tracey, declaring that the jurisdiction of service tribunals

will prevail so long at any rate as the rule which it prescribes is sufficiently connected with the regulation of the forces and the good order and discipline of defence members... ${ }^{69}$

However, in dissenting from the judgment of the majority, Callinan and Heydon JJ adopted a more qualified 'service connection' approach. Their Honours paid particular attention to the fact that the discipline of the ADF would be enhanced by the enforcement of a section of the Act. As their Honours remarked:

\footnotetext{
${ }^{67}$ Ibid 324.

${ }^{68}$ Ibid 319.

${ }^{69}$ Ibid 329.
} 
If the test of service connexion is to be applied on the basis that it will be satisfied if the acts alleged constitute an undisciplined application of force, or conduct that would be regarded as abhorrent by other soldiers, then it is difficult to see how any serious crime committed anywhere, including in Australia, under any circumstances would not be susceptible to the military jurisdiction exclusively. The further consequence would be the denial to the soldier and the prosecuting authority of trial by jury. It is sometimes overlooked that the prosecuting authority and the community which it represents have as great as [sic] and as real an interest in trial by jury as the person on trial. We do not, with respect, therefore subscribe to the view that to ask the question whether the discipline of the military service will be enhanced by a certain measure or course, is to ask the same question as 'Is there a service connexion?' Any measure for the proscription of any form of misconduct has as its end, discipline. If enhancement of discipline is to be effectively the only test, there will be very few offences of any kind, committed anywhere, in any countries, which will escape the all-enveloping net of 'service connexion'. 70

Thus, their Honours would seem to be suggesting that the proper focus should be less on service connection and more on whether the discipline of the ADF would be enhanced by the enforcement of the section of the Act. ${ }^{71}$ In the end, Callinan and Heydon JJ dissented on the application of this test to the facts, finding that there was no sufficient association between the actions of the service tribunal or magistrate and the promotion of discipline. Accordingly, their Honours stated that:

Nothing that the prosecutor was alleged to have done was done under colour of any military authority, or was or could have been done because he was a member of the Defence Force, or was materially facilitated by reason of his membership in it. The alleged offence was totally unconnected with any military duty. ${ }^{72}$

Kirby J also adopted the 'service connection' test as the applicable basis on which to evaluate the jurisdiction of the magistrate's action - 'in the absence of a wider argument ... challenging the validity of the provisions of the Act under Ch. III, and in order to refine the point upon which the court now divides'. ${ }^{73}$ In supporting such an approach, Kirby J stated that:

it is my view that unless a service tribunal is established under Ch. III of the Constitution it has jurisdiction to deal with an 'offence' by a member of the

\footnotetext{
${ }^{70}$ Ibid 359.

${ }^{71}$ Devereux, above n 10, 491.

${ }^{72}$ (2004) 220 CLR 308, 358.

${ }^{73}$ Ibid 337.
} 
armed forces only if such an 'offence' is exclusively disciplinary in character or is concerned with a distinct disciplinary aspect of conduct constituting an offence against general law. ${ }^{74}$

In dissenting from the majority and finding that no proper connection could be drawn between the offence as charged and the regulation and discipline of the defence forces, Kirby J particularly pointed to the fact that Australia was at peace at the time and that Private Alpert was not, at the time of the commission of the offence, in combat. Further, Kirby $\mathrm{J}$ also drew attention to the fact that the accused was not in a location where there was no effective law. These factors, according to his Honour, all militated against an association being established between the offence and the proper or effective functioning of the defence forces. As Kirby J stated:

The constitutional position might be different were those circumstances different ... (2) the issue of constitutional validity is also to be assessed upon the basis that Australia is presently at peace. The special needs of the $\mathrm{ADF}$ in respect of discipline in times of war (or other times when the services 'stand in most urgent need' of disciplinary powers) were inapplicable at the time of the prosecutor's alleged offence; (3) the offence did not occur in the actual theatre of combat or during military, policing or peacekeeping operations in which, whether at home or abroad, special needs for military discipline might be inherent in the functions of 'defence'; and (4) the case is not one where the accused was in a place outside Australia 'beyond the reach of the ordinary criminal law' or where there is no effective law at all... ${ }^{75}$

Kirby $\mathrm{J}$ also made particular reference to important considerations in relation to the constitutional separation of powers doctrine, holding that because military service tribunals were not Chapter III courts they could only exercise jurisdiction on matters that were exclusively concerned with the discipline of the ADF:

[I]t is my view that unless a service tribunal is established under Ch. III of the Constitution, it has jurisdiction to deal with an 'offence' by a member of the armed forces only if such an 'offence' is exclusively disciplinary in character or is concerned with a distinct disciplinary aspect of conduct constituting an offence against the general law. ${ }^{76}$

\footnotetext{
${ }^{74}$ Ibid 333.

${ }^{75}$ Ibid 333.

${ }^{76}$ Ibid 337.
} 
Consequently, his Honour held that there was insufficient connection between the offence and the effective regulation and discipline of the military to support the jurisdiction of the service tribunal over the charge. Despite these dissenting judgments - of Callinan and Heydon JJ, as well as Kirby J the four judges of the majority were of the view that the application of section 61 to the circumstances of the soldier was, in fact, a valid exercise of the defence power of the Commonwealth. As previously outlined, Gleeson $\mathrm{CJ}$, McHugh, Hayne, and Gummow JJ all held that the provision in the Defence Force Discipline Act punishing a member of the Australian Defence Force for a sexual offence committed while the service member was on leave had the purpose of maintaining military discipline. As Gleeson CJ concluded:

[W]hile defence members serving overseas must obey local laws, the imposition of minimum standards of behaviour by reference to Australian law is a legitimate means of preserving discipline bearing in mind that Australian forces might be located in places where there is no government or where there is a hostile government... If it is accepted to be a proper concern of Parliament to require defence members, when serving overseas, to behave according to standards of conduct prescribed by Australian law then there is power to impose such requirements generally... ${ }^{77}$

\section{CRItique of AIRD AND the DEFENCE ForCe DISCIPLINE ACT}

The case stated for consideration of the full court of the High Court in Re Colonel Aird was 'insofar as s 9 of the Defence Force Discipline Act ("DFDA") purports to apply the provisions of that Act, including s 61 DFDA so as to permit the trial by general court martial under the Act of the Prosecutor in respect of the alleged offence ... is it beyond the legislative power of the Commonwealth and, to that extent, invalid?? ${ }^{78}$ According to Tracey, there is now 'a significant risk that the same act might render the service member liable to prosecution in both a service tribunal and a civil court for what could be both an offence under the Act and a civilian criminal offence. ${ }^{79}$ The basis for this contention is that the legitimacy of service tribunals to adjudicate on charges against members of the ADF effectively constitutes an exception to the provisions of Chapter III of the Constitution

\footnotetext{
77 (2004) 220 CLR 308, 313.

78 (2004) 220 CLR 308, 309.

${ }^{79}$ Richard Tracey, above n 6, 429. However, in his dissenting judgment, Kirby J agreed with Deane J's approach that the doctrine of the separation of powers meant service tribunals could only be given jurisdiction under s 51(vi) to deal with exclusively disciplinary offences.
} 
and that this exception must, therefore, be strictly confined or limited to matters related to the operation of the ADF.

To overcome this criticism, further limitations would need to be imposed on the capacity of the defence power to support provisions of the Defence Force Discipline Act which seek to regulate defence members who are on leave or who are acting in an essentially private capacity. On this issue, Mitchell and Voon advocate, in effect, a 'two step' test for delineating the scope of the defence power in relation to service tribunals hearing charges against members who, at the time of the commission of an offence, are not directly involved in military or defence force activities. First, Mitchell and Voon (following the approach of the majority in Aird's case) ask whether:

trying the offence would substantially serve the purpose of maintaining or enforcing the discipline of the defence forces. If the answer is no - the offence falls outside s 51(vi) of the Constitution and should not be tried in a service tribunal $\ldots{ }^{80}$

This first test would seem to be simply a reiteration of the 'service connection' test that was outlined by the majority in Aird.

Secondly, Mitchell and Voon require that, in order to trigger the operation of the defence power and in order to come within its scope, there must be some minimum content or substance in the statutory offence or provision of the legislation that links it with the defence power, or that delineates it as a provision that has been enacted pursuant to the defence power. As the authors emphasise, the jurisdiction of service tribunals in these matters, and the provisions of the Defence Force Discipline Act allowing them to try defence force members, constitute exceptions to the jurisdiction of Chapter III courts. Accordingly, so as not to offend the separation of powers principle, there needs to be shown in the legislative provisions or jurisdiction of the service tribunal some minimum connection or association with the defence force. When outlining the second element or aspect of their test the authors state:

Second, adopting the approach of Deane J, we ask whether trying the offence would fall within the minimum jurisdiction necessary for service tribunals to maintain or enforce military discipline. If not, only a Chapter III court may validly try the offence. It is this requirement that stems from Chapter III and the doctrine of separation of powers. The exception to the separation of powers principle applies to cases that fall within the minimum

\footnotetext{
${ }^{80}$ Mitchell and Voon (2005), above n 34, 412.
} 
jurisdiction necessary for military discipline... Our proposed test resolves several problems that various justices identified in Re Aird... ${ }^{81}$

This requirement of a 'minimum content' or 'minimum substance' of military discipline would appear to overcome the problem associated with the constitutionality of service tribunals exercising jurisdiction in matters that are essentially civil or private law offences. In the context of the facts of Aird, whilst the accused soldier was charged with a civil offence - that of rape and was on leave during the time of the commission of the offence, there was little difficulty in establishing a connection or association between this offence and the effective regulation and discipline of the military. This was because there is a minimum set of standards of conduct of behaviour to which serving personnel had to adhere even if they were 'on leave' and not acting in the line of military duty.

As Hyder Gulam emphasises, the discipline and the morale of the defence force are critical to the efficacy of the defence force and thus provide an accurate indicator or test of whether there is a sufficient 'defence' content in the legislation or jurisdiction of the service tribunal:

Morale and discipline of the armed forces are at the heart of military effectiveness. Members of the ADF must have a clear understanding of the standards of conduct to which they must conform and they must also have confidence that the system of justice will operate in a fair and just manner. The primary mission of the ADF is to defend Australia's national interest by preparing for and, when necessary, waging war, using coercive and lethal force... Military discipline exists for the protection, not the persecution, of ADF personnel. Discipline is not the fear of punishment for doing something wrong, but faith in the value of doing something right. This aspect of military discipline is often misunderstood. A disciplined defence force does not mean cowering in fear of the punishment. It means requiring personnel who will do the right thing in all situations... ${ }^{82}$

What remains to be seen, however, is whether the 'service connection' test can be further extended to other situations, such as those involving military reservists, who are not engaged in active full-time service. While the 'service connection' was successfully applied to the situation of a defence force member who was on leave at the time of the commission of the offence in Aird, it is unclear whether it will be applicable to the situation of army reservists. As John Devereux argues:

\footnotetext{
${ }^{81}$ Ibid 412.

${ }^{82}$ Gulam, above n 6, 240.
} 
What is the service connection test which applies to reservists not undertaking continuous full time service? What if the accused in Aird had been a reservist? Defining the scope of the service connection test for reservists may have enormous consequences in defence. ${ }^{83}$

In this context too it is worth noting the extensive attention paid by Mitchell and Voon to the international comparative situation vis-à-vis conflict between separation of powers doctrines, individual rights and maintenance of an effective defence force. Besides the examples of the Federal Republic of Germany and Sweden, they cite Black $\mathbf{J}$ in the United States Supreme Court who observed in Toth v Quarles: 'free countries of the world have tried to restrict military tribunals to the narrowest jurisdiction deemed absolutely essential to maintaining military discipline among troops in active service. ${ }^{, 84}$

\section{CONCLUSION}

This article has sought to canvass the relatively recent jurisprudence relating to the Defence Force Discipline Act 1955 (Cth) as well as to analyse critically the provisions of the Act itself. As has been shown, there have been two predominant tests that have sought to ground the constitutionality of the provisions of the Defence Force Discipline Act and their application to acts by members of the ADF. The first test has been the so-called 'service status' approach which essentially regarded the fact that the accused was a member of the defence force as a sufficient connection for the triggering of the jurisdiction of the Act and the federal defence constitutional power. The second test, and the one that has received approval by a majority of the present High Court, has been the 'service connection' approach which requires that the provisions of the Defence Force Discipline Act contribute to, or promote, the effective discipline and functioning of the military. As we have attempted to show here, the Australian case law on the Defence Force Discipline Act over the past two decades has reflected, in various degrees, elements of both these approaches. The High Court's decisions in Re Tracey and Re Nolan, for example, particularly reflected the divergent approaches which the individual justices have taken to assessing the validity of the Act and the constitutionality of the exercise of jurisdiction by military tribunals and other courts martial. In Re Tracey, in particular, Mason CJ, along with Wilson and Dawson JJ would seem to have adopted a particularly wide approach, finding that it was sufficient that the person charged was a member

\footnotetext{
${ }^{83}$ Devereux, above n 10, 492.

${ }^{84}$ Mitchell and Voon, (1999), above n 34, 523ff.
} 
of the defence force to trigger the jurisdiction of the Act and of the Defence Force Magistrate. On the other hand, Brennan and Toohey JJ, as well as Deane $\mathrm{J}$ in Re Tracey required a more definite connection or association between the offence charged and the ADF, thereby advocating the adoption of a 'service connection' test. As was shown, this division was further reflected in the subsequent decision in Re Nolan; Ex parte Young wherein Mason CJ and Dawson J adopted a 'service status' test while Brennan and Toohey JJ, as well as Deane $\mathrm{J}$ and Gaudron $\mathrm{J}$ embraced a 'service connection' test.

The High Court, however, now seems, in its judgment in Aird's case, albeit by a 4:3 majority, to have settled on the use of the 'service connection' test. As has been shown, however, the use or employment of this test by a majority of the Court in Aird has not been without criticism. One criticism has been that the test allows service tribunals to prosecute criminal cases which have little or nothing that is particularly related to the defence forces or military. It has been argued that the exercise of jurisdiction by service tribunals breaches the separation of powers doctrine and is unconstitutional since service tribunals are not Chapter III courts and are not exercising power in relation to distinctively defence or military matters. As a result of this, Mitchell and Voon suggested a modification of the 'service connection' test (as outlined by the High Court) through the insertion of an additional 'minimum content' requirement in relation to defence matters in order to trigger the operation of the defence power. Yet, as we have shown, this further requirement adds little to the 'service connection' test and proof that the offence prejudices the discipline and effective functioning of the ADF would seem to be a sufficient basis on which to trigger the jurisdiction of the service tribunal and the operation of the defence power. It is still unclear, however, whether the 'service connection' test will operate as effectively in those cases involving military reservists who are not full-time serving members of the ADF.

Furthermore, recommendations of the Senate, Foreign Affairs, Defence and Trade Reference Committee have been adopted, and much of this complexity may be avoided in the future. Recommendations from this committee advocated the establishment of a Permanent Military Court to enforce and apply the provisions of the Defence Force Discipline Act. What is significant is that the Court is to have all of the associated trappings of a properly constituted Chapter III court. The judges of this court, for example, will have tenure and they will be entirely independent of the defence force. With the establishment of the Military Court, much of the debate about whether the 'service status' test or 'service connection' test is most appropriate in 
triggering the constitutional defence power and the jurisdiction of courts martial and defence tribunals will no longer be so imperative. The jurisprudence to date will, however, stand as a reminder of the extent to which military matters, and, in particular, the appropriate scope of the defence power in times of both war and peace, remain essentially contested and subject to ongoing academic debate and judicial contention and controversy. Such reflections could pivot around Kirby J's views as he approaches retirement, including his warning that the extension of jurisdiction into 'non-service related' offences, including that of rape, pushes 'the boundary of service discipline beyond its constitutional limits' and would effectively render the requirements of connection to some aspects of national defence meaningless. ${ }^{85}$ Each time the High Court has considered the issue of validity of military service tribunals it has upheld their validity 'to conduct trials and impose punishment' as pertinent exercises of the defence power. ${ }^{86}$ It is timely to conclude with the resounding reflection upon the scope of the defence power by Kirby $\mathrm{J}$ in Aird, where he reminds us that ' $[\mathrm{t}]$ he Constitution is a living document. It adapts and changes with the changing circumstances of Australia and the world to which it must apply. ${ }^{87}$

\footnotetext{
${ }^{85}$ (2004) 220 CLR 308, 339.

${ }^{86}$ Mitchell and Voon, above n 34, 499.

${ }^{87}$ (2004) 220 CLR 308, 342.
} 
